\title{
CROSS BORDER LISTING AS MEANS OF AGRICULTURAL ENTERPRISE FINANCING
}

\author{
Andriy Popovych, $\mathrm{PhD}^{1}$ \\ Institute of Agroecology and Environmental Management
}

\begin{abstract}
The international shares placement via IPO on the WSE by several Ukrainian companies, mainly from the sector of agricultural production and processing, makes an appealing case of relatively quick and inexpensive access to foreign borrowing markets. The WIG Ukraine index shows optimistic start, period of positive gains, dramatic fall at one point and significant volatility afterwards due to both the political and macroeconomic upheavals in the home country as well as internal problems of emitents. The comparison with other indexes of WSE and other exchanges reasonably suggests that the latter reason was the main cause of the deterioration of the indicator. The investigation on the parameters of the regression model that describe time series of WIG-Ukraine index with the help of the ARIMA model reveals that short-time predictions dominate investors decisions.
\end{abstract}

Keywords: agriculture holding, international IPO, ARIMA model

JEL codes: G15, F37, Q14

\section{INTRODUCTION}

Over the past decade, several major trends have been observed in the strategy of Ukrainian agricultural enterprises such as expansion of land bank, increasing storing capacity and introduction of modern technologies which require significant investments. This entails the access to the international capital market, including mergers and acquisitions. It is the aspiration of middle-level agricultural companies to grow into the agricultural holding through the accumulation of land and attracting international investment (Stecjuk, 2010).

To further develop agro-holdings are considering various methods of financing, one of which is an IPO on global stock exchanges. While in Ukraine the stock market never passed the stage of formation Ukrainian companies in the agrarian and food sector have already placed an IPO on stock exchanges in other countries. About a dozen Ukrainian agro-holdings went to the Warsaw Stock Exchange (WSE), the London Stock Exchange and Deutsche Börse.

The numerous international IPO's of Ukrainian agricultural companies during the short period make a very interesting case of cross-border listing which has not yet been reflected in academic literature. This study aims to fill this gap by qualitatively and quantitatively analysing the performance of Ukrainian agro-holdings' stocks on WSE. Additional task is to develop an instrument for analysing the behaviour of investors and movements of stocks prices of WSE emitents from Ukraine.

${ }^{1}$ Corresponding author: Metrologichna 12, 03143 Kyiv, Ukraine, apopovych@kse.org.ua, +38 (095) 1918335 


\section{THEORETICAL BACKGROUND}

Maximizing the value of shareholders' shares is the most important reason why a company may seek to become public one. If the company's management is confident in its good prospects in the market, then the IPO can be more profitable for shareholders than selling the business of another company. The price of shares after the start of trading may grow, and the cost of shares in the company of its original shareholders will increase (Gutorov, 2012). Business valuation of a listed company is usually higher because the liquidity of publicly traded shares is higher.

The IPO allows attracting money on more favourable terms attracting large amounts from private investors. The IPO allows attracting significant financial resources to improve business efficiency - modernization and renovation of the fleet of vehicles, expansion of the land bank, development of infrastructure, etc. without increasing the debt burden (Gutorov, 2012). Such a new status allows the company to speed up the pace of development, and also to start cooperation with the best international and European banks. Another reason is obtaining an acquisition tool to pay for merged companies in case of growth by buying competitors and suppliers and sellers not only with money, but also with shares of the 'parent' company. The same reason applies to hiring qualified employees with offer not only money but also shares as compensation. The additional gain is raising public awareness of company, products and services because an IPO is an event that draws the attention of the press and the public.

But all this, in turn, requires high transparency of doing business and obliges the company to publication of quarterly and annual reports, regular audits. Transparency of the enterprise is not limited to covering financial and operational information. The company should also fully disclose both the structure of owners and the remuneration of top management. Moreover, such companies are constantly in the field of vision of the state and inspection bodies, which cannot always have a positive effect on their activities (Ghosh and Lee, 2013).

The public placement on international stock exchanges has gained popularity among Ukrainian ag- ricultural producers about a decade ago, in the middle of 2000s. Due to the fact that the IPO require the companies to be ready for a long and extensive work on preparation only leaders in the domestic and foreign agricultural markets could successfully increase capitalisation in after IPO period (Gudz', 2009).

\section{MATERIALS AND METHODS}

Warsaw Stock Exchange plays the role of main financial hub for Ukrainian companies allowing quickly and inexpensively to reach foreign investors. The main advantage of WSE is that Polish investors are more tolerant to medium-sized companies from Ukraine than investors on other international stock platforms. This exchange is most suitable for companies with a capitalization of USD 100-150 million.

The choice of Ukrainian agricultural companies to enter the WSE as issuers was driven by the following factors: a relatively smaller amount of accommodation costs, minimum requirements for listing, territorial proximity of the markets of Ukraine and Poland. Moreover, Polish investors better than others understand the specifics of Ukrainian business environment, pricing system, legal structure. In addition, the WSE requirements for the issue of prospectus are close to Ukrainian regulations (Zelisko, 2011).

The most active Ukrainian issuers on the Warsaw Stock Exchange were agricultural companies. By the end of 2013, the last time IPO-activity of Ukrainian companies on WSE was observed, they attracted almost USD 500 million on this exchange, which is about $6 \%$ of the capital attracted by all Ukrainian companies through IPO. The best results on the IPO among Ukrainian companies can be observed in cases of placements of Astarta, Kernel and Ovostar.

The trend line of capitalization of Ukrainian agribusinesses on WSE shows that loses in market value of agricultural holdings started from the very beginning of the current decade, reached the trough in middle and followed by steeper growth afterwards. If in early years investors were ready to buy shares of companies in the agricultural sector of Ukraine by the middle of the decade the demand for them declined. Ukraine agro-industrial complex have ceased to be attractive to investors due to changes in the Polish 
legislation related to pension reform and following reduction of assets of pension funds.

The main threat for Ukrainian companies is that the Polish investors are losing confidence in Ukrainian issuers because of the failure of them to report properly and timely. Most Ukrainian emitents most often do not attach due importance to communication of information on all aspects of company's activity to investors, limiting it to the minimum required by the exchange. Thus, in case of unforeseen situations such as a decline in product prices, freezing of a bank account, closure of trade routes, etc., accompanied by silence from companies, portfolio managers are pressured to sell such securities.

\section{RESULTS AND DISCUSSION}

The WIG-Ukraine index includes shares of Ukrainian companies listed on the WSE Main Market which at present happens to be only representatives of agriculture and food sector. WIG-Ukraine is an income index and it includes both the prices of the shares it contains and the income from dividends and preemptive rights. The WIG-Ukraine index is calculated from 31 December 2010 and follows the principle of diversification aimed at limiting the share of a single company. However due to the short list the structure of WIG-Ukraine is dominated by the aggregate share of agricultural holdings of Kernel and Astarta which is more than $70 \%$ and which makes the index extremely dependent on the situation in these companies.

The index of shares of Ukrainian companies at present continues to restore lost points after a major fall in 2014-2015 but the trading volume of the remaining Ukrainian companies included in WIGUkraine is still quite low. The dynamics of quotations of Ukrainian agro-corporations on the WSE since August 2015 was positive for 8 out of 9 whose securities added in price from 35 to $135 \%$. But at the same time, the excess of the current price over the face value of shares is observed only in four companies whose securities are quoted on the WSE. Moreover, the rating of Ukrainian companies was negatively affected by the delisting of several companies such as KSG AGRO, Sadovaya Group SA and Westa.

At the beginning and end of 2017, capitalization of companies in WIG-Ukraine index was in the range of EUR 2.6-2.7 billion which indicates certain stability in the value of Ukrainian agro-holdings in the world market. This supports the view that agricultural sector of Ukraine is traditionally the strongest part of national economy, showing a high level of profitability and growth potential. Although with eight issuers representing this segment of the Ukrainian economy on the WSE, its attractiveness in the eyes investors is no longer so obvious, belonging to the agricultural sector is still a fundamental factor for investors.

The growth of WIG-Ukraine is supported by the process of resolving the political and military crisis in the country, the image component of the Ukrainian revolution and relative calm in the east of Ukraine. The further behaviour of the index will in the main depend on the direction of developments in the country and in agricultural sector. In the case of a positive resolution of the crisis in eastern Ukraine, the shares of Ukrainian companies should show the significant growth. The latest financial reports from Ukrainian agricultural holdings on WSE shows significant improvements the bottom lines which suggests the growth in the value of the shares and the volume of trading of the largest Ukrainian companies placed on the WSE and make it possible to predict the further growth of the WIG-Ukraine index.

The WIG-Ukraine can be compared to other WSE country or regional indexes such as WIG-CEE and WIG-Poland. The WIG-CEE index includes only shares of companies listed on the WSE from Central and East European countries while WIG-Poland index includes only shares of domestic companies listed on the WSE Main Market. The WIG-Ukraine index is showing the similar pattern to WIG-CEE index although latter is more flat while the behaviour of WIG-Poland index demonstrates quite different dynamics.

The data are from Warsaw Stock Exchange ${ }^{2}$ consist of time series on WIG-Ukraine, WIG-Poland and

${ }^{2}$ Warsaw Stock Exchange webpage https://www.gpw.pl/Indeks. 
Proceedings of the 2018 International Scientific Conference 'Economic Sciences for Agribusiness and Rural Economy' No 1, Warsaw, 7-8 June 2018, pp. 309-314

WIG-CEE indexes from the dates of their initiation until 21 May 2018. The closing value is chosen to represent the index as it reflects all the activities of the index. Main parameters of the data are presented in Table 1.

The absolute value of the Pearson correlation coefficient of 0.16 corresponds to a very low crossover between the WIG-Ukraine and WIG-Poland while between WIG-Ukraine and WIG-CEE it was
0.78 which indicates strong connection. The latter is explained by the fact that the stocks of Ukrainian companies on WSE are included in the index of WIG-CEE. The correlation coefficient between WIG-Poland and WIG-CEE at the level of -0.4 is a sign of connection of medium tightness. These correlations are statistically significant $(p<0.01)$. The results of correlation analysis are presented in Table 2.

Table 1. Data description

\begin{tabular}{|l|c|c|c|c|c|c|c|c|}
\hline Index & $N$ & $\bar{x}$ & $\mathrm{SD}$ & Skewness & Kurtosis & $\begin{array}{c}\text { Jarque- } \\
- \text { Bera test }\end{array}$ & Low & High \\
\hline WIG-Ukraine & 1844 & 553.85 & 196.0295 & -0.44025 & 7.4651 & 1590.533 & 216.73 & 1089.8 \\
\hline WIG-Poland & 1760 & 51024.57 & 7672.976 & -0.57509 & 6.0683 & 787.404 & 36088.06 & 69047.45 \\
\hline WIG-CEE & 1844 & 855.41 & 114.8457 & 0.15179 & 7.8473 & 1812.350 & 643.63 & 1117.48 \\
\hline
\end{tabular}

Source: WSE.

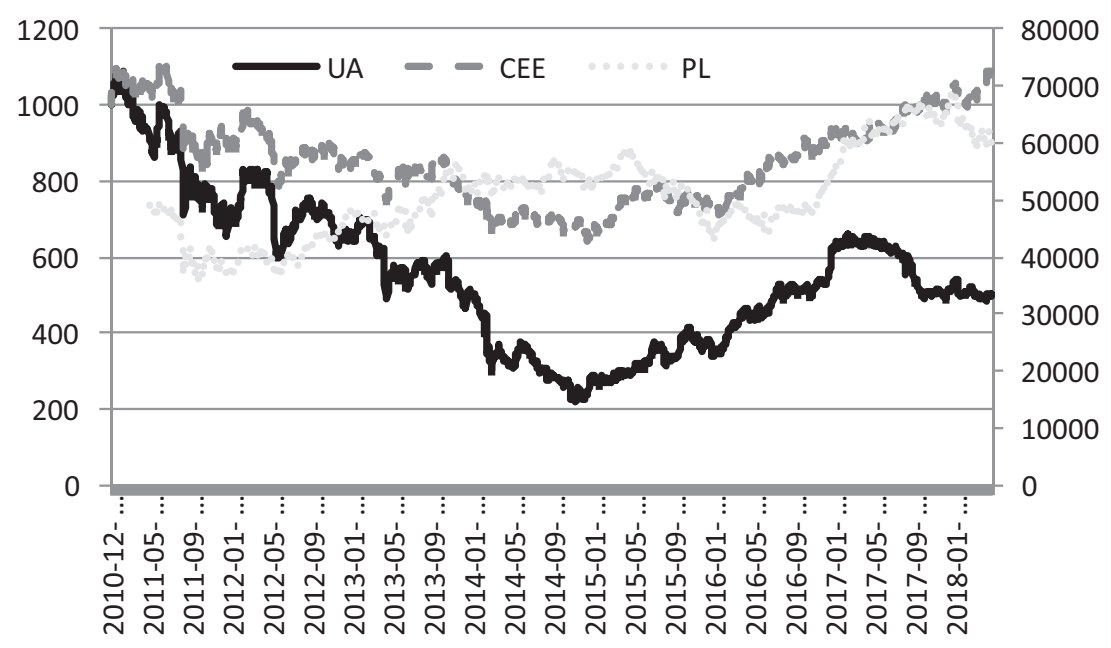

Figure 1. WIG-Ukraine, WIG-CEE, WIG-Poland indexes in 2010-2018 (points)

Source: WSE.

Table 2. Pearson correlation

\begin{tabular}{|l|c|c|c|}
\hline Specification & WIGUKR $\sim$ E & WIGPOL D & WIGCEE \\
\hline WIGUKR $\sim$ E & 1.0000 & - & - \\
\hline WIGPOL D & 0.1628 & 1.0000 & 1.0000 \\
\hline WIGCEE & 0.7825 & -0.3987 & - \\
\hline
\end{tabular}

Source: WSE. 
For econometric analysis of indexes the Autoregressive Integrated Moving Average (ARIMA) model based on the premise that past values have an effect on current values and therefore predicts future behaviour based on past behaviour is chosen. ARIMA models are commonly used to predict the future values of the variable which makes them popular for analysing nature, economics, and other time-varying processes but this statistical technique is the most prominent method in financial forecasting (Rangan and Titida, 2006; Merh, Saxena, and Pardasani, 2010).

ARIMA models are efficient in generating forecasts and constantly outperformed complex structural models in short-term prediction (Meyler, Kenny and Quinn, 1998). The results obtained with ARIMA model demonstrated their potential to predict stock prices satisfactory on short-term basis which could guide investors in stock market (Adebiyi, Adewumi and Ayo, 2014).

The specification of the model in this study is referred to as $\operatorname{ARIMA}(1,1,1)$ meaning autoregressive and moving average process is the first order processes and the differencing of observations to make the time series stationary is performed one time. The value of $\log$ likelihood component of ARIMA model (ignoring negative sign) is 6,587 which is sufficiently high. The coefficient of AR is less than 1 and is significant at $5 \%$ while the MA coefficient is significant as well as and lesser than 1, which suggests that differenced time series is stationary. The results of ARIMA model application to index of WIG-Ukraine are presented in the Table 3. The application of ARIMA model to the WIG-CEE and WIG-Poland indexes does not produce the easily interpreted results.

The results obtained with ARIMA revealed that the investors in stocks of Ukrainian agricultural companies base their expectations on recent performance of stocks. Because of lack of father and more broad view the investors overreact to any negative news from the country or from the emitent which explains the higher level of volatility (Renhao et al., 2015). The results of variance test indicate that the volatility of WIG-Ukraine index is higher compared both to the WIG-Poland and WIG-CEE. At the same time the variability of WIG-Poland was lower than WIG-CEE.

The specification of obtained ARIMA model on WIG-Ukraine suggests that small-scale investors while taking decisions may not possess all the necessary information. They are considering only the information on the stock conduct in close vicinity of the moment because the Ukrainian agro holdings do not communicate with investors properly and timely.

\section{CONCLUSIONS}

Ukrainian agribusiness needs long-term investments and the primary placement on international exchanges is one of the ways of attracting capital. The popularity of the Warsaw Stock Exchange among Ukrainian agricultural producers is primarily due to its close proximity and the comparatively low cost of conducting an IPO. The securities of 9 companies of the

Table 3. WIG-Ukraine ARIMA model results (Stata v. 12)

\begin{tabular}{|l|c|c|c|c|}
\hline D. OPG & Coefficient & SE & $z$ & $P>z$ \\
\hline ar: L1. & 0.4993971 & 0.082282 & 6.07 & 0.000 \\
\hline ma: L1. & -0.3583992 & 0.089436 & -4.01 & 0.000 \\
\hline cons & -0.2692482 & 0.268024 & -1 & 0.315 \\
\hline Log likelihood & -6587.021 & $\times$ & $\times$ \\
\hline Wald $\chi^{2}(2)$ & 215.25 & $\times$ & \\
\hline Prob. $>\chi^{2}$ & 0.000 & \multicolumn{3}{|c|}{} \\
\hline
\end{tabular}

Source: author's calculations. 
agro-industrial complex of Ukraine are circulating on the Warsaw Stock Exchange and after experiencing the steep decline in 2011-2014 presently demonstrate the positive dynamics. The index of shares of Ukrainian agro-holdings listed on WSE WIG-Ukraine is more volatile if compared to the other indexes. The specification of ARIMA model shows that the trend in stock prices of WIG-Ukraine is self-sustaining due to limited information for taking decisions by the investors.

\section{REFERENCES}

Adebiyi, A., Adewumi, A., Ayo, C. (2014). Stock price prediction using the ARIMA model. In: Proceedings - UKSim-AMSS 16th International Conference on Computer Modeling and Simulation, UKSim 2014. DOI: 10.1109/ UKSim.2014.67

Ghosh, A., Lee, Y.G. (2013). Financial reporting quality, structural problems and the informativeness of mandated disclosures on internal controls. Journal of Business Finance and Accounting, 40 (3-4), pp. 318-349.

Gudz', O.J. (2009). Suchasnyj vymir finansovogo zabezpechennja vyrobnychoi' dijal'nosti agroformuvan' [Modern Dimension of Financial Provision of Productive Activity of Agricultural Enterprises]. Oblik i Finansy APK, 2, pp. 8-12.
Gutorov, A. O. (2012). Korporatyzacija sil's'kogo gospodarstva v Ukrai'ni [Corporatization of Agriculture in Ukraine]. Ekonomika i Prognozuvannja, 4, pp. 82-92.

Merh, N., Saxena, V.P., Pardasani, K.R. (2010). A Comparison Between Hybrid Approaches of ANN and ARIMA For Indian Stock Trend Forecasting. Journal of Business Intelligence, 3 (2), pp. 23-43.

Meyler, A., Kenny, G., Quinn, T. (1998). Forecasting Irish Inflation using ARIMA Models. Central Bank of Ireland Research Department, Technical Paper.

Rangan, N., Titida, N. (2006). ARIMA Model for Forecasting Oil Palm Price. In: Proceedings of the 2nd IMT-GT Regional Conference on Mathematics, Statistics and Applications. Universiti Sains Malaysia, Pinang.

Renhao, J., Wang, S., Yan, F., Zhu, J. (2015). The Application of ARIMA Model in 2014 Shanghai Composite Stock Price Index. Science Journal of Applied Mathematics and Statistics, 3 (4), pp. 199-203.

Stecjuk, P.A. (2010). Peredumovy ta mozhlyvosti rozvytku integrovanyh agroformuvan': finansovyj aspekt [Prerequisites and Opportunities for Development of Agroformations: financial aspect]. Visnyk Hark. nac. tehn. un-tu sil's'kogo gospodarstva. Ekonomichni nauky, 99, pp. 245-252.

Zelisko, I.M. (2011). Garmonizacija finansovogo mehaniz$\mathrm{mu}$ integraciji agrarnyh formuvan' [Harmonization of the Financial Mechanism for the Integration of Agroformations]. Ekonomika APK, 5, pp. 121-124. 